\title{
KIDNAPPING MENACE: CAUSES AND EFFECTS ON HOTEL BUSINESSES IN GHANA
}

\author{
Noble Amoako Sarkodie, Augustina Aggrey and Elizebeth Dwomor \\ Sunyani Technical University, Ghana \\ Department of Hospitality and Tourism
}

\begin{abstract}
The purpose of the study was to ascertain the influence of kidnapping on hotel business in Ghana. The study adopted survey design covering a cluster sample of 60 managerial staffs drawn from 5, 4 and 3- star hotels across major cities in the country. Questionnaire was the main data collection instrument and data analysed through descriptive statistics. The study identified unemployment, poverty, greed, politics, illiteracy, rituals and spiritual proclivity as major causes of kidnapping in the country. The study further revealed influence of kidnappings on hotel businesses as: reduction in guest patronage, decreases in profitability, increases in expenditures on security and high level of mistrust among staff. Finally, the study showed that training anti-kidnapping agencies, heavy punishments for offenders, job creation, and education were possible solutions to the menace of kidnapping in Ghana. It is, therefore, recommended that efforts be made by government to create more job avenues to tackle the problem of unemployment and create public awareness of the citizen's safety and security. It is envisaged that the study would be beneficial to the government, practitioners of hospitality and tourism industry, hospitality and tourism educators and security agencies.
\end{abstract}

Key words: Kidnapping, kidnapper, menace, combat, victim, abduction

\section{INTRODUCTION}

Kidnapping is a global problem that affects countries all over the world. Therefore, governments over the world are working hard to ensure that it is minimised and that perpetrators are arrested and prosecuted. According to Hakeem, (2016), kidnapping refers to forceful abduction of a human being with the intention to hold victims for ransom.
The crime of kidnapping occurs when a person is taken from one place to another without his/her consent and the person is confined to a particular place without legal authority. Usually, kidnappers carry their victim to a location that tracing of the person becomes difficult. These acts of criminality facilitate other offences such as rape, robbery, assault and murder (Abraham, 2013).

The role of Hospitality and Tourism industry in the world economy cannot be underestimated. For instance, it is estimated that by 2022 , the hospitality industry would employ about 328 million of the global work force both directly and indirectly (Hilton Worldwide, 2013). In Ghana, the Hospitality and Tourism sector of the economy is the third foreign exchange earner and contributes 3.7 percent of the country's Gross Domestic Product (GDP) (Havi \& Enu 2013). In terms of direct revenue, the tourism sector generates about GH 4.457 billion cedis per annum which is expected to increase to GH 7.449 billion cedis by 2026(www.myjoyonline.com/news/2017/April-24th).

However, kidnapping has, of late, become endemic in the Ghanaian society especially in SekondiTakoradi, Kumasi and Accra where in 2019; there were 13 reported cases of kidnapping and abduction of women and girls (www.wanep.org). Instances were where the three Ghanaian girls kidnapped in Sekondi - Takoradi, two Canadians, and charity volunteers, abducted in Kumasi and an Estonian diplomat seized in Accra during his regular morning walk (www.wanep.org).

These developments have the potential to scare away foreign investors and visitors to the country. It can further affect the perception of the country by the international community as an unsafe destination for tourism with the potentials of slowing down revenues and employment from the industry. Edmonds and Mark, (2008) asserted that, a reduction in the number of visitors to tourist attraction sites has the inevitable 


\section{International Journal of Engineering Applied Sciences and Technology, 2020 \\ Vol. 5, Issue 4, ISSN No. 2455-2143, Pages 484-494 \\ Published Online August 2020 in IJEAST (http://www.ijeast.com)}

implications on revenue, employment and stakeholders in the tourism and hospitality industry.

If this trend continues unabated, it may have dire consequences on demand for hospitality services. It is upon this, that the researchers sought to investigate the causes, the effects and suggests some possible solutions to kidnapping activities.

\section{OBJECTIVES OF THE STUDY}

The main objective of the study is to ascertain the influence of kidnapping on hotel business in Ghana. Specifically, the study sought to:

1. identify factors that cause kidnapping on hotel business.

2. examine the effects of kidnappings on hotel business.

3. suggest possible solutions to the menace of kidnapping.

\section{LITERATURE REVIEW}

\section{Definitions of Kidnapping}

Abraham (2013) defined kidnapping as an act of seizing, taking away and keeping a person in custody either by force or fraud. Davidson (2010) also defined kidnapping as the act of taking somebody away illegally and keeping them as a prisoner, especially in order to get money or something else for returning them. According to Hakeem, (2016), kidnapping refers to forceful abduction of a human being with the intention to hold them for ransom, or seize them away for the motive of harassment (physically or mentally or sexually), taking them hostage and various other motives.

Thomas and Nta (2009) further, defined kidnapping as robbery of the highest rank. According to them, it is an organized and systematic robbery which is not as deadly as armed-robbery, but more profitable than the former. The profitability has encouraged those that indulged in it to carry on with the act although there is a law prohibiting it. In criminal law, kidnapping is defined as taking away of a person by force, threat or deceit with intent to cause him/her to be detained against his or her will (Asuquo, 2009). Nwaorah (2013) also, defined kidnapping as an act of an angry man who wants to take any person of value hostage and who could be rescued by loved ones.
According to Ogabido (2011), kidnapping means to abduct, capture, carry off, remove or steal away a person(s). Dode (2007) further, defined kidnapping as a process of forcefully abducting a person or group of persons perceived to be the reasons behind the injustice suffered by another group.

\section{Types of Kidnapping}

There are many more different types of kidnapping. These include kidnapping for ransom, tiger kidnapping, express kidnapping, political kidnapping and virtual kidnapping.

\section{Kidnapping for ransom}

Kidnapping for ransom happens when a criminal abducts a person as a hostage in order to receive money from their family, employer in exchange for the victim's release (Partlow, 2014). According to Zanonni (2017), kidnapping for ransom is a varied and developing phenomenon, but it is most common in countries with high levels of crime and corruption, poorly resourced or trained police personnel, a weak judiciary, and/or a history of political or social instability and conflict.

\section{Tiger kidnapping}

In this type of kidnapping, the hostage is forced to follow the kidnappers' directions and perform their desirable actions. For example, the bank employee may be forced to open up the vault. Another horrible example of this type of kidnapping is when the hostage is forced to plant a bomb (Petersen, 2008).

\section{Express kidnapping}

Here, the kidnappers abducts the victims, takes them to an Automatic Teller Machine (ATM) and forces them to withdraw cash. Usually, this type of kidnapping does not involve violence and it is relatively fast. Express kidnapping is a very common type of abductions in Latin America and Africa (Echeburua, Corral, \& Armor, 2010).

\section{Virtual kidnapping}

The newest form of kidnapping is a virtual abduction, and it does not actually involve physical kidnapping. The criminal would call the victim's family and demand ransom for the release of their family member. The requested amount is relatively smaller so that the chances of a quick payment are higher. The main instrument of this type of kidnapping is threats without any proofs. The criminal's goal is to scare the family members, so that they believe their relative is in danger (Partlow, 2014). 


\section{Factors that Cause Kidnapping}

\section{Unemployment}

The high unemployment rate in many countries has forced some citizens to find other illegal means to make money especially when the youths become idle; they usually resort to all manner of nefarious activities. The study of Kilishi, Mobolaji, Usman, Yakubu and Yaru (2014) established that the rising trend of crime is usually blamed on the high rate of unemployment. Suleiman, (2017) further argued that the problem of unemployment in Africa is one of the major syndromes that upturned youths to become atrocious actors. A cash-strapped unemployed person may believe that when he kidnaps someone who is rich, he may be able to become rich himself (Christie, 2017).

\section{Poverty}

Poverty is one of the major causes that usually push people to go into the act of kidnapping. Poverty is a state of lacking basic requirement to live rational life. Basic requirement such as money, food, water and shelter, among others, are the scourge of poverty which demoralised the less privilege to be inflicted with the wrath of anomaly (Suleiman, 2016).

A study carried out by Abraham (2013) disclosed that poverty has twisted many youths to become disreputable kidnapers due to the implacable famine and deficient means to survive economic downturn. Also, sometimes, a poor person might believe that kidnapping could provide the necessary money to start a new life, a life that will no longer involve crime (Christie, 2017).

\section{Illiteracy}

Illiteracy is the inability to read or write. When people know how to read and write, they can gain the skills they need in order to secure a job, and live a productive life. Mohamed (2008) study pointed out that kidnappings and bombings perpetrated by the militant Islamic group in Nigeria, are caused by illiteracy, at least in part. The leaders of this group provide the perpetrators with falsehood information, which the men cannot disprove by reading outside sources (Mohamed, 2008).

\section{Religion}

Many kidnappings in the world today have their root cause in religion. Some people love their religion so much that even when it teaches them something that is wrong, they believe it is right. One religious leader may want to take over another group and order his men to kidnap his rivals (James, 2013). It emerged from Usman (2017) study that religion is a cause of kidnapping.

\section{Greed}

Some people are not content with what they have and wish they could buy more and more things, whether it's fancy clothes, cars, houses, or jewelry. This person may turn to crime to make more money. A wicked businessman can kidnap his business rival for a large ransom to become richer (James, 2013).

\section{Ritual and spiritual proclivity}

Kidnapping for ritual involves killing or severing the body part of abducted persons for the purpose of using it as an object of ritual sacrifice aimed to acquire ritual money, favour, fame, success, power and protection (Oyewole, 2016). Kidnapping for ritual is an unlawful seizure of a person in order to kill and/or sever part of his or her body for the purpose of ritual sacrifice (Oyewole, 2016). Human sacrifice is a blood sacrifice that involves killing of a living creature as a ritual offering to a god or spirit, usually in expectation of a return in the form of good fortune (La-Fontaine, 2011). The process often involves victims that are charmed and made unconscious by the abductors at the point of capture.

\section{Politics}

Emanemua and Akinlosotu (2016) emphasised that the political importance of thugs and hooligans to party aspirants during campaign periods, seem to have had a trickle down and spill-over influence on several innocent citizens. Previously, jobless youths that were recruited by political godfathers to cause chaos, steal ballot boxes, and even kidnap viable political members from opposing parties has now taken up their seasonal job as a full time business. Emanemua and Akinlosotu, (2016) also postulate that, politicians sometimes, do this so that their opponents will make concessions or change their views on the issues.

Effect of Kidnappings on the Hospitality Industry Kidnapping affects not only the hotel industry of a country directly involved but neighboring countries and regions as well. Since overwhelming evidence suggests that terrorism and political turmoil do negatively affect tourism in target countries, it behooves one to remember that tourists have alternatives (Gu, \& Martin 2016). The notion that tourists are rational individuals who would rather avoid costs than incur them plays an important role 


\section{International Journal of Engineering Applied Sciences and Technology, 2020}

Vol. 5, Issue 4, ISSN No. 2455-2143, Pages 484-494

Published Online August 2020 in IJEAST (http://www.ijeast.com)

here. For instance, when tourists perceive a destination as risky and thus costly, they substitute it for another destination deemed more stable and less costly (Gu, \& Martin 2016).

In furtherance, kidnappers usually target tourism infrastructure which attracts foreign investment and thereby discourage potential investors from bringing their capital to a country affected by kidnapping in the short and longer terms which leads to loss of revenues (Baker and David 2013). In a society where the incidence of kidnapping is high, fear limits people's lives and actions. They will always move with caution as they do not know who might be the next target. The rich surround themselves with security guards because of their fear of getting kidnapped (Baker and David, 2013).

In other related research conducted by Kaylor (2015) found out that kidnappings reduces demand for goods and services of hotels during violent periods (for example, going to a hotel). Hotels that face a high probability of being victimised by kidnappings may face tighter financial constraints (Kaylor, 2015).

Shuaibu, Salleh and Shehu (2015) also found that hotels with high records of kidnappers face higher security costs such as bodyguards, armored cars and intelligence services. Kidnappings further, reduce investment through a decrease in local consumption; investment by hotels companies that have access to alternative markets should be less sensitive to kidnappings than investment by hotels that sell in local markets only (Shuaibu, Salleh \& Shehu, 2015).

It also, emerged from Gaviria's (2017) study, that a hotel that sells in other markets like travel and tour business may be able to shift production to that market when local demand of their product falls.

\section{METHODOLOGY}

Descriptive survey design was employed to execute the study. The population composed of managerial staffs working in three to five- star rated hotels. Managers were considered because they were experts and might be able to tell whether kidnappings have effects on hotel businesses. The study further employed cluster sampling technique to gather data from 60 respondents drawn from 5, 4 and 3- star hotels in Accra, Kumasi, Sekondi- Takoradi, CapeCoast and Sunyani. A questionnaire was used to gather data from the respondents. The questionnaire had two parts. Part "A" had items, which elicited data about respondents' background information whilst Part "B" of the questionnaire elicited information about causes, effects and solutions to kidnappings. The items on the questionnaires were of the closeended type to make it easy for respondents to tick the answer which was applicable. Questionnaires were finally delivered to respondents at their working places. Further, the data gathered was analysed using computer software, Statistical Product Service Solution (SPSS v. 20). Frequency distribution was used to analyses background characteristics of the respondents' gender, educational level, age range and number of years of working in the hotel whilst descriptive statistics of mean and standard deviations were used for the analysis to provide data on causes and effects of kidnapping on hotel businesses in Ghana. 


\section{RESULTS AND DISCUSSION}

Table 1: Socio-Demographic Characteristics of Respondents

\begin{tabular}{|c|c|c|}
\hline \multirow[b]{2}{*}{ Variables } & \multicolumn{2}{|c|}{ Managers } \\
\hline & Freq. & $\%$ \\
\hline \multicolumn{3}{|l|}{ Gender } \\
\hline Male & 38 & 63 \\
\hline Female & 22 & 37 \\
\hline \multicolumn{3}{|l|}{ Educational level } \\
\hline Secondary & 2 & 3 \\
\hline HND/Diploma & 10 & 17 \\
\hline Bachelor Degree & 45 & 75 \\
\hline Master's Degree & 3 & 5 \\
\hline \multicolumn{3}{|l|}{ Age range (Years) } \\
\hline Below 20 & 0 & 0 \\
\hline $20-29$ & 6 & 10 \\
\hline $30-39$ & 15 & 25 \\
\hline $40-49$ & 28 & 47 \\
\hline Above 50 years & 11 & 18 \\
\hline \multicolumn{3}{|c|}{ Numbers of years working } \\
\hline Less than 2 years & 8 & 13 \\
\hline $3-6$ years & 34 & 57 \\
\hline $7-10$ years & 6 & 10 \\
\hline $11-15$ years & 12 & 20 \\
\hline More than 15 years & 0 & 0 \\
\hline
\end{tabular}

Source: Field Survey, 2020

Table 1 presents socio-demographic characteristics of respondents. For the managerial staff, 37\% were females while $63 \%$ were males. It can be stated that, majority $(63 \%)$ of the respondents who participated in the study were males.

In terms of educational levels of respondents, 3\% of them had attained Secondary Education, 10\% of them had attained HND/Diploma education, and 75\% had attained bachelor degrees while 2\% mentioned Master's degree. This means that the respondents used for the study possesses varied levels of educational qualifications. 
For the age range, $10 \%$ of the respondents were aged between $20-29$ years, $25 \%$ were aged between $30-39$ years, and $47 \%$ were within the age range of $40-49$ while $18 \%$ were above 50 years. This implies that most of the respondents used for the study are within active working class age group. It is also observed that, $57 \%$ of respondents have worked in the hotel for 3-6 years, $13 \%$ have worked for less than 2 years while $20 \%$ have worked for 11-15 years. This implies that all the respondents possess varied years of experience which makes them eligible to give reliable information about the issues in the study.

Table 2: Causes of Kidnapping

\begin{tabular}{lcc}
\hline Factors that Cause Kidnapping & Mean & Std. Dev. \\
\hline Unemployment & 3.75 & 0.70 \\
Poverty & 3.70 & 0.74 \\
Illiteracy & 2.50 & 1.24 \\
Religion & 2.17 & 1.16 \\
Greedy & 3.60 & 0.82 \\
Ritual and spiritual proclivity & 3.80 & 0.64 \\
Politics & 2.83 & 0.90 \\
Mean of means & $\mathbf{3 . 1 9}$ & \\
\hline Source: Fid Survey
\end{tabular}

Source: Field Survey, 2020

Scale: Mean range of 1.0-2.4 =Disagree, 2.5-3.9 =Agree

Generally, the mean of means (3.19) indicates that the variables identified in the study are possible factors that contribute to kidnapping. Majority of the respondents agreed $(\mathrm{M}=3.80)$ that ritual and spiritual proclivity are major causes of kidnapping in hotels. The study's finding is interesting since science has not yet sufficiently explained human sacrifice through ritual kidnapping. Thus, implying that there is no evidence linking human sacrifices to making anyone rich. The study finding is similar to Oyewole (2016) and Ezemenaka (2018) studies that found that many people were kidnapped and later recovered with their head being cut off, eyes removed, genital and breast severed, arm and leg amputated. Respondents further, agreed $(\mathrm{M}=3.75)$ that unemployment is a cause of kidnapping. The study results convey a message to government to create more job avenues for the citizens in order to minimise kidnappers from the society.

In addition, respondents agreed $(\mathrm{M}=3.70)$ that poverty is one of the causes of kidnapping. The result of the study is a wakeup call to government to create enabling environment for the establishment of businesses by individuals and organisations to create more employment to enhance the livelihood of the citizens. The study result is consistent with the findings of Suleiman (2016) and Christie (2017) who disclosed that poverty has twisted many youths to have become disreputable kidnapers due to the implacable famine and deficient means to survive economic downturn.

The respondents were further in agreement that greed is a cause of kidnapping $(\mathrm{M}=3.60)$. The finding of the study, gives credence to the fact that kidnapping plays very critical role in altruistic social behaviour.

Additionally, respondents agreed $(\mathrm{M}=2.83)$ that politics is a cause of kidnapping. The results corroborate the outcomes of studies conducted by (Emanemua \& Akinlosotu, 2016). The empirical evidence emanated from their research suggested that corrupt politicians may arrange for the kidnapping of their opponents so that their opponents will make concessions or change their views on issues. In furtherance, illiteracy and religion were causes of kidnapping with a mean score of $(\mathrm{M}=2.50)$ and $(M=2.17)$ respectively. The study finding of illiteracy as one of the causes of kidnapping implies that parents need to be encouraged by the findings of this study to ensure good parenting and educate their children since education enhances full development of the child. Further, the study finding of religion as 


\section{International Journal of Engineering Applied Sciences and Technology, 2020}

Vol. 5, Issue 4, ISSN No. 2455-2143, Pages 484-494

Published Online August 2020 in IJEAST (http://www.ijeast.com)

cause of kidnapping demonstrated that religion plays

a mediating role in the members.

Table 3: Effect of Kidnappings on Hotel Business

\begin{tabular}{lll}
\hline Effect of Kidnapping & Mean & Std. Dev. \\
\hline Kidnapping reduces guests patronage & 3.78 & 0.72 \\
It decreases profitability of hotel & 3.70 & 0.74 \\
Kidnapping increases expenditures on preventive measures & 3.60 & 0.88
\end{tabular}

People tend to stay clear from the hotel and the adverse effect is always on the economy

$3.64 \quad 0.84$

Loses a lot of revenue when expatriates working in the hotels are attacked

$3.70 \quad 0.80$

It also contributed to a high level of mistrust among people working in hotels

$\begin{array}{lll}\text { Mean of means } & 2.54 & 1.27 \\ & \mathbf{3 . 4 9} & \end{array}$

Source: Field Survey, 2020

Scale: Mean range of 1.0-2.4 =Disagree, 2.5-3.9=Agree

The mean of means (3.49) shows that kidnapping has significant effect on hotel business. From Table 3, majority of the respondents agreed $(\mathrm{M}=3.78)$ that kidnapping reduces guests patronage of hotels. The finding implies that potential guests normally stay away from hotels for fear of being kidnapped. The outcome corroborates that of Baker (2014) which found that kidnapping affects the number of tourists patronising hotel since many tourists are no longer visiting hotels due to fear of kidnapping. The respondents were further in agreement that kidnapping decreases profitability of hotel with a mean score of $(\mathrm{M}=3.70)$. Implying that hotel businesses would suffer reduced profits. Again, respondents agreed $(\mathrm{M}=3.60)$ that that kidnapping increases expenditures on preventive measures. The finding corroborates the outcome of a study conducted by Lennon and O'Leary (2015) which revealed that kidnapping indirectly increases hotel expenditures on preventive measures, such as the employment of private security personnel, installation of surveillance equipment and introduction of other security enhancing measures.

Furthermore, respondents agreed $(\mathrm{M}=3.64)$ that people tend to stay clear from the hotel and the adverse effect is always on the economy. The study finding is consistent with Lennon and O'Leary (2015) that found that people tend to stay away from the hotel for fear of being kidnapped.

Additionally, respondents agreed $(\mathrm{M}=3.70)$ that kidnapping leads to loses of revenue to government when expatriates working in the hotels are attacked. The study makes a very vital contribution to the field of hospitality and tourism industry by providing empirical evidence of the extent to which kidnappers' activities significantly influenced hotel businesses. Finally, the respondents agreed $(M=2.54)$ that kidnapping leads to high level of mistrust among the staff in a hotel. The results convey a message to stakeholders of hospitality practitioners that not all staff could be trusted as some staff members could condone and connived with the perpetrators to carry out their evil activities. The outcome of the study is also in line with the finding of a study by Okwuagbala (2017) which found some level of mistrust among the staff in the hotel. 


\section{CONCLUSIONS AND RECOMMENDATIONS}

The study was embarked upon to examine the influence of kidnapping on hotel business drawn from 5, 4 and 3- star hotels in Sekondi- Takoradi, Kumasi, Cape - Coast, Accra and Sunyani in Ghana. Although a lot of studies had been conducted on the subject, researchers had been silent on the influence of kidnapping on hotel business in Ghana. The results of the study revealed that unemployment, poverty, greed, politics, illiteracy, rituals and spiritual proclivity as major causes of kidnapping. The study further revealed influence of kidnappings on hotel businesses as: reduction in guest patronage, decreases in profitability, increases in expenditures on security and high level of mistrust among the staff. Based on the findings of the study, the researchers recommend the following:

1. It is recommended that government should create more job avenues to tackle the problem of unemployment in the country.

2. It is recommended that harsh punishments should be meted out to kidnappers when arrested to serve as deterrents to others.

3. The government and hospitality practitioners should increase support to strengthen the capacity of the security agencies through training, provision of equipment, and increase presence of security in order to combat the activities of kidnappers.

4. It is recommended that, government should ensure increased access to technical and vocational education to the people. When people are equipped with knowledge and skills especially technical and vocational education, they tend to apply the knowledge acquired to better their lives. Hence lead to productive life and improve the standard of living of the people. Pannel (2016) asserts that education enables students to acquire competencies, which are utilised in turning resources for the benefit of individuals and societies.

5. It is recommended that, employees should be given good remuneration to avoid desperation in search of alternative means for money.

\section{REFERENCES}

[1] Abraham, W. (2013). Shaking hands with the Devil: The intersection of Terrorism and

Theology. . USA: Highland Loch Press.

[2] Adesina, O. (2013). Unemployment and Security Challenges in Nigeria. International

Journal of Humanities and Social Science 3(6), 146156.

[3] Asuquo, M. E. (2009). The upsurge of kidnapping and its influence on Public order in Akwa

Ibom State. Unpublished Term Paper Department of Sociology/Anthropology, University of

Uyo, Uyo, Akwa Ibom State- Nigeria.

[4] Baker, D. \& David, M.A. (2013). Effects of sudden and dramatic events on travel desire and

risk Judgements. Scandinavian Journal of Hospitality and Tourism, 11(3), 9-12.

[5] Baker, D. A. (2014). The effects of kidnapping on the travel and tourism industry.

International Journal of Religious Tourism and Pilgrimage 2(1), 9-13.

[6] Christie, S. (2017). 'Truly despicable.' Who is Karen Matthews and why did she kidnap

Shannon? UK's 'most hated mom' who abducted her own daughter," . The Sun.

[7] Davidson, G. (2010). Crime and the Human Mind. New York: Columbia University Press.

[8] Dode, R. O. (2007). Incidents of Hostage Taking and the Niger Delta Crisis in Nigeria.

South-South Journal of Culture and Development 9 (1), 162-179.

[9] Echeburua, E., Corral, P., \& Armor, P. J. (2010). Evaluation of Psychological Harm in the

Victim of Violent Crime. . Psychology in Spain, 7, , $10-18$. 


\section{International Journal of Engineering Applied Sciences and Technology, 2020 \\ Vol. 5, Issue 4, ISSN No. 2455-2143, Pages 484-494 \\ Published Online August 2020 in IJEAST (http://www.ijeast.com)}

[10] Edmonds, C., \& Mak, J. (2008). Terrorism and Tourism in the Asia Pacific Region: Is

Travel and Tourism in a new World after 9/11? East West working Papers: Economic Series.

[11] Emanemua, A.B. \& Akinlosotu, T.N. (2016). Kidnapping for ransom in Nigeria:

Implications and Quest for a Permanent Solution. International Journal of Arts and Humanities

5, 17-20.

[12] Ezemenaka, K.,E. (2018). Kidnapping a security challenge in Nigeria. Journal of Security and

sustainability issue 8(2):233-246.

[13] Gaviria, A. (2017). Assessing the effects of kidnapping on hotel Performance: Evidence from Latin America," Emerging Markets Review 3 (2): 245-268.

[14] Gu, Z. \& Martin, T. L. (2016). Terrorism, seasonality, and international air tourist Arrivals

in Central Florida: An empirical analysis. Journal of Travel and Tourism Marketing 3(1), 3-15.

[15] Hakeem, J. (2016). Uran Legislators Lament over Kidnapped Indigene - A Year without

Trace .

[16] Havi, E., P.,K. \& Enu, P.(2013). The impact of tourism on economic performance in

Ghana.European Scientific Journal December 2013, 9(34). ISSN: 1857-7881.

[17] Hilton Worldwide ( 2013). Creating opportunities for youth in hospitality. Retrieved from

http://www.iyfnet.org/sites/default/files/CreatingOpportunities-forYouth-in-Hospitality.pdf

Weekly Insight, August 6, 5.
[18]James, B. (2013). Handbook for treatment of attachment trauma problems in children. . New

York: The Free Press.

[19] Kayani, M. M., Akbar, R. A., Faisal, S., Kayani, A. \& Ghuman, A. (2017). Analysis of socioeconomic benefits of education in developing countries: An example of Pakistan. Bulletin of Education and Research, 3, 75-92.

[20] Kaylor, L. (2015). Psychological impact of human trafficking and sex slavery worldwide: Empowerment and intervention. John Jay College of Criminal Justice, New York,NY

[21] Kilishi, A.A., Mobolaji, H.I., Usman, A., Yakubu, A.T. \& Yaru, M.A. (2014). The effect of

unemployment on crime in Nigeria: A panel data analysis. British Journal of Economic

Management \& Trade 4(2), 880-895.

[22] Klein, S \& Alexander, D. (2016). Kidnapping and hostage-taking: a review of effects,coping

and resilience. Journal of the Royal Society of Medicine 3(2), 223-226.

[23] La-Fontaine, J. (2011). Ritual Murder?, Interventions Occasional Paper Series 3, Open

Anthropology Cooperative Press.

[24] Lennon, R. \& O'Leary, B. (2015). A comparison of the effect of international terror attacks

on German and American Consumers' Perceptions and future travel Plans. Journal of Accountin

\& Finance Research, 13(2), 181-191.

[25] Mohamed, M. K. (2008). Kidnap for Ransom in South East Asian: The case for a regional

recording standard.Asia Criminology, 3, 61-73.

[26] Nwaorah, N. (2013). Are kidnappers worst criminals? Vanguard, March 29, p. 14. 
[27] Ogabido, G. O. (2011). Kidnapping: New Brand of Terrorism. Saturday Sun, October 31, p.

7.

[28] Oyewole, S. (2016). Kidnapping for rituals: Article of faith and insecurity in Africa. Journal

of Pan African Studies 9, 35-52.

[29] Partlow, J. (2014). Kidnappings in Mexico Surge to the Highest Number on Record.

[30] Petersen, W. H. (2008). Countering the threat of kidnapping. . Risk Management,5, 1-6

[31] Shuaibu, S. S., Salleh, M. A. \&Shehu, A. Y. (2015). The impact of Boko Haram

insurgency on Nigerian national security. International Journal of Academic

Research in Business and Social Sciences. 5 (6), 254-266.

[32] Suleiman, A. (2017). Thematic Appraisal on the Impulsive Upsurge of Yahoo-Yahoo in The

21st Century in Nigeria: Qur'ānic Standpoint.

[33] Thomas, T. \& Nta, P. . (2009). Kidnapped and persecuted coman Clem's Wife, a 5 Year Old

Girl. Community Pulse, August 10, p. 6.

[34] Usman,E.(2017). Why killings for rituals are on the increase in Nigeria, Vanguard September.

https://www.vanguarding.com.

[35]www.wanep.org/wanep/files/2019/Jun/Peace_an d_Security_Report_on_Ghana_Final_26-06-2019.

[36] www.myjoyonline.com/news/2017/April24th/travel-tourism-contributed-gh45b-to-2015-

gdp.php

[37] Zannoni, I. E. (2017). Understanding and managing the threat of kidnapping. Retrieved from

Available at http://securitysa.com/article.asp?pkl 
International Journal of Engineering Applied Sciences and Technology, 2020

Vol. 5, Issue 4, ISSN No. 2455-2143, Pages 484-494

Published Online August 2020 in IJEAST (http://www.ijeast.com) 